\title{
An antioxidant activity of Cinnamonum tamala improves histopathological alterations and biochemical parameters in alloxan induced diabetic rats
}

\author{
Mamta Pochhi \\ Associate Professor, Department of Biochemistry, Shri Shankaracharya Institute of Medical Science, Bhilai, India
}

\section{A B S T R A C T}

Background: Diabetic mellitus is a multifactorial disorder associated with its devastating consequences has assumed epidemic proportion. Diabetes mellitus (DM) is a global health problem and the incidence of DM is increasing at alarming rate all over the world. Many Indian medicinal plants have been reported to possess potential antidiabetic activity and could play important role in the management of diabetes with less adverse effects. Aims and Objectives: The main objective of this study was to focus on the anti-diabetic activity of Cinnamomum tamala, with special reference to its curative and protective role in alloxan induced diabetic rats. Attempts were further made to study the antioxidant properties of C. tamala leaves. Materials and Methods: The diabetic rats were administered orally with the aqueous leaves extracts of Cinnamonum tamala $(250 \mathrm{mg} / \mathrm{kg})$ for 30 days. The results were compared with standard drug Tolbutamide. Result: The alloxan treated diabetic control rats showed a significant increase in the plasma glucose, glycosylated hemoglobin $(\mathrm{HbA} 1$ ), glucose-6-phosphatase, aldolase, LDH, ALT, AST, ALP and GGT activity, free radicals formation with a concomitant decrease in glycogen content in the liver and serum insulin level and phosphoglucoisomerase and hexokinase activity in tissues as compared to normal control rats. Oral administration of $\mathrm{C}$. tamala extract for 30 days showed significant result as compared to Tolbutamide and diabetic control rats. Conclusion: On the basis of above findings it can be concluded that extracts of $C$. tamala to alloxan induced diabetic rats showed significant positive changes in the biochemical and histopathological parameters related to carbohydrate and protein metabolism. Further studies should be undertaken to find out the molecular mechanism of C. Tamala.

Access this article online

Website:

http://nepjol.info/index.php/AJMS DOI: 10.3126/ajms.v10i6.25609 E-ISSN: 2091-0576 P-ISSN: 2467-9100

Key words: Cinnamonum tamala; Blood glucose; Insulin; Glycogen; Glycosylated hemoglobin; Marker enzymes; Antioxidants; Histopahological findings

\section{INTRODUCTION}

Diabetes mellitus $(\mathrm{DM})$ is a chronic endocrine disorder, involving metabolic disorders of carbohydrate, proteins, and fats resulting from inadequate pancreatic insulin secretion with or without concurrent impairment of insulin action. ${ }^{1}$ According to the American diabetes association, the chronic hyperglycemia is associated with long-term damage, dysfunction, and failure of different organs, especially the eyes, kidneys, nerves, heart and blood vessels. ${ }^{2}$
Previous studies have demonstrated that DM exhibits enhanced oxidative stress and highly reactive oxygen species (ROS) production in pancreatic islets due to persistent and chronic hyperglycemia, there by depletes the activity of the antioxidative defense system, and thus promotes free radical generation. ${ }^{3}$ Oxygen free radicals have been suggested to be a contributory factor in complications of $\mathrm{DM}^{4}$ and the antioxidants may be useful in preventing it. ${ }^{5}$ Therefore supplementation of therapeutics with antioxidants may have a chemoprotective role in diabetes. ${ }^{6}$ 
Many Indian medicinal plants have been found to be useful because of rich source of various bioactive phytochemicals in the management of diabetes. Medicinal plants provide better alternatives as they are less toxic, easily available and affordable and many of the currently available drugs have been derived directly or indirectly from them. ${ }^{7,8}$

C. tamala is belonging to the Lauraceae family. The leaves, known as tejpat, tejpatta, or tejpata in Hindi, tamalpatra in Marathi, and Indian Cassia in English which is widely used in pharmaceutical preparations because of its hypoglycemic, stimulant and carminative properties. ${ }^{9}$ Leaves of this plant are effective in diabetic rats have antioxidants as well as have hypoglycemic antiinflammatory and immunomodulation properties ${ }^{10}$ and the bark was reported to have anti-diabetic activity by using $\alpha$-amylase inhibition assay. ${ }^{11,12}$

Only scarce data is available on effect of C. tamala on other parameters. Our aim was to explore the antioxidant activity of $\mathrm{C}$ tamala improves histopathological alterations and Biochemical parameters in alloxan induced diabetic rats and compare the effect with standard drug Tolbutamide.

The Indian medicinal plant Cinnamomum tamala Nees and Eberm or Indian bay leaf is an evergreen, mediumsized tree belonging to the family Lauraceae. The leaves, known as tejpat, tejpatta, or tejpata in Hindi, tamalpatra in Marathi, and Indian Cassia in English, are usually olive green in colour, may have some brownish spots and have three veins running down the length of the leaf. The leaves of this tree have medicinal properties and are reported to be used in treatment of numerous ailments. The produce of the plant is also used as food, fodder, medicine and timber in Uttarakhand state as well as in other Himalayan regions of India. ${ }^{4}$ Various kinds of leaf extracts of C. tamala have previously been reported to have anti-inflammatory, ${ }^{5}$ antioxidant, ${ }^{6}$ antiulcer, ${ }^{7}$ anticarcinogenic, ${ }^{8}$ antidiarrhoeal ${ }^{9}$ and antidiabetic. ${ }^{10}$

\section{Preparation of plant extract}

The leaves of C.tamala were collected locally. Plants were confirmed by Taxonomist.

For preparation of aqueous $C$. tamala, leaves were properly clean and powdered in an electrical grinder and stored at room temperature. About $20 \mathrm{~g}$ of dry leaf powder was mixed in $100 \mathrm{ml}$ of distilled water at $100^{\circ} \mathrm{C}$ for the preparation of aqueous hot extracts. The flasks were kept overnight. Supernatant was filtered with muslin cloth and filtered twice with Whatman No. 1 filter paper. The supernatant collected was dried to form gel. Water extract were lyophilized and stored at $4^{\circ} \mathrm{C}$ until used.

\section{Doses}

$250 \mathrm{mg} / \mathrm{kg}$ body wt/day of powder of C.tamala dissolved in $5 \mathrm{ml}$ of $\mathrm{D}$. water given to experimental rats orally.

\section{Selection of animals}

Male albino rats weighing 100-150 grams were used for the experiments in the present study. The animals were fed with standard laboratory diet and allowed to drink water ad libitum under well ventilated conditions of $12 \mathrm{~h}$ light/ dark cycles in the animal room of Government medical College, Nagpur during the experimental period.

\section{Induction of diabetes}

Group I rats were injected with distilled water as a normal control. Overnight fasted rats in groups II, III, IV and V were administrated a single intraperitoneal injection of a freshly prepared aqueous solution of alloxan at a dose of $18 \mathrm{mg} / \mathrm{kg} / \mathrm{wt}$. The animals were considered as diabetic, if their blood glucose values were above $200 \mathrm{mg} / \mathrm{dl}$ on the $3^{\text {rd }} \mathrm{d}$ after alloxan injection. The treatment was started on the $3^{\text {rd }}$ day after confirmation of diabetic condition with C tamala $(250 \mathrm{mg} / \mathrm{kg} / \mathrm{wt})$ and Tolbutamide $(300 \mathrm{mg} / \mathrm{kg} / \mathrm{wt})$ in $10 \%$ ethanol solution to group IV and V respectively, which was considered as the $1^{\text {st }} \mathrm{d}$ of treatment. The treatment was continued for 30 days.

At the end of experimental period, the animals were deprived of food overnight and sacrificed by decapitation at the end of respective experimental periods. The whole blood and serum collected was used for biochemical estimations. The liver was excised immediately and thoroughly washed with ice-cold physiological saline and stored at $-20^{\circ} \mathrm{C}$ until further used.

\section{Analytical methods}

Autozyme kits were obtained from 6Ranbaxy and Accurex Biomedical PVT LTD. diagnostic company.

Plasma glucose $e^{13}$, glycosylated hemoglobin ${ }^{14}$, Insulin ${ }^{15}$, liver glycogen $^{16}$, Hexokinase ${ }^{17}$, Pglucoisomerase ${ }^{18}$, Aldolase $^{19}$, LDH $^{20}$,Glucose-6- phosphatase ${ }^{21}$, AST, ALT ${ }^{22}$, ALP $^{23}$, GGT, GSH level ${ }^{24}$ and SOD. ${ }^{25}$

\section{Histopathological investigation}

Liver tissues for histopathological analysis were fixed in 10\% formalin solution. After fixation, tissues were embedded in paraffin; solid sections were cut at $4 \mu \mathrm{m}$ and stained with haematoxylin and eosin. ${ }^{26}$ The sections were examined under light microscope, and photomicrographs were taken.

\section{Statistical analysis}

All the data were statistically evaluated and the significance calculated by using student's test. All the results were expressed as mean \pm SEM. 


\section{RESULT}

The result revealed in Table 1, that after 30 days treatment, it was observed that the animals treated with C.tamala extract $(250 \mathrm{mg} / \mathrm{kg})$ and Tolbutamide showed significant decrease in glucose $(\mathrm{P}<0.01)$, glycosylated hemoglobin $(\mathrm{P}<0.01)$ in experimental diabetic rats. There was also increased in glycogen content of liver $(\mathrm{P}<0.05)$ with significant increased in Insulin level $(\mathrm{P}<0.01)$ with C. tamala or tolbutamide treatment as compared to diabetic control.

Table 2 shows the significant improvement in the activity of Glucose metabolizing enzymes (Hexokinase, aldolase, LDH, P-gluco isomerase and Glucose- 6- phosphatase).

Table 3 the data shows the decreased in liver enzymes (AST, ALT, ALP and GGT).

Table 4 reveals a significant decrease in antioxidant enzyme activities SOD and antioxidant GSH were observed in the hepatic tissues in diabetic conrol group when compared with normal control group.But after treatment with C.tamala extract in diabetic rats shows significant raised in SOD and GSH level as compared with DC group.

\section{Microscopic examination}

The effects of C. tamala on histopathology of liver in alloxan induced diabetic rats are shown in Figures 1-4.

\section{DISCUSSION}

Diabetes mellitus is currently a major public health concern, because its incidence and prevalence are elevated and increasing, reaching epidemic proportions. ${ }^{27}$ Cumulative evidence has shown that poorly and erratically controlled hyperglycemia produces abnormally high levels of $\mathrm{ROS},{ }^{28}$ and these reactive substances could react with essential molecules such as lipids, proteins and DNA, leading to histological changes as well as functional alterations. $^{29}$

\begin{tabular}{|c|c|c|c|c|c|}
\hline Groups & Treatment & PI.Glucose (mg\%) & $\mathrm{HbA} 1_{c}(g m \%)$ & Liver Glycogen mg/g & Insulin $(\mu \mathrm{lU} / \mathrm{mL})$ \\
\hline $\mathrm{GrI}$ & Normal & $84.37 \pm 0.63$ & $5.75 \pm 1.10$ & $17.05 \pm 0.49$ & $2.83 \pm 0.08$ \\
\hline Gr II & D. Control & $254.47 \pm 1.73^{d}$ & $8.1 \pm 1.50^{c}$ & $8.55 \pm 0.35^{d}$ & $1.25 \pm 0.10^{c}$ \\
\hline Gr III & D. control & $278.83 \pm 0.78$ & $8.73 \pm 0.10$ & $8.5 \pm 0.26$ & $1.23 \pm 0.12$ \\
\hline Gr IV & D+C. tamala & $94.82 \pm 0.54^{c}$ & $7.38 \pm 0.27^{c}$ & $12.92 \pm 0.09^{a}$ & $2.45 \pm 0.16^{c}$ \\
\hline Gr V & D+Tolbutamide & $115.3 \pm 0.29^{d}$ & $7.78 \pm 0.16$ NS & $12.69 \pm 0.34^{c}$ & $2.23 \pm 0.10^{\mathrm{a}}$ \\
\hline
\end{tabular}

Values are given as mean $\pm S D(n=6)$. Values were statistically significant at ${ }^{a} P<0.05,{ }^{b} P<0.02,,{ }^{c} P<0.01,{ }^{d} P<0.001$. Normal Vs $D$. control and Diabetic Control Vs Diabetic treated albino rats

\begin{tabular}{|c|c|c|c|c|c|c|}
\hline Groups & Treatment & $\begin{array}{l}\text { Hexokinase (nM } \\
\text { of glu6Po formed/ } \\
\text { min/mg protein) }\end{array}$ & $\begin{array}{l}\text { P-gluco isomerase } \\
\text { (nM of fruformed/ } \\
\mathrm{min} / \mathrm{mg} \text { protein) }\end{array}$ & LDH (U/L) & $\begin{array}{l}\text { Glu6tpase (nM } \\
\text { of Pi liberated/ } \\
\mathrm{min} / \mathrm{mg} \text { protein) }\end{array}$ & $\begin{array}{c}\text { Aldolase (nMof } \\
\text { glyceraldehyde } \\
\text { formed/min/mg protein) }\end{array}$ \\
\hline Gr I & Normal & $302.00 \pm 4.04$ & $37.21 \pm 0.26$ & $96.00 \pm 0.28$ & $49.76 \pm 0.41$ & $222.00 \pm 0.11$ \\
\hline Gr II & D. Control & $67.4 \pm 0.38^{d}$ & $15.90 \pm 0.13^{c}$ & $195.06 \pm 0.15^{c}$ & $134.85 \pm 0.15^{c}$ & $273.88 \pm 0.26^{d}$ \\
\hline Gr IV & D+C.tamala & $295.65 \pm 0.29^{c}$ & $38.78 \pm 0.26^{c}$ & $95.26 \pm 0.40^{c}$ & $41.5 \pm 0.52^{\mathrm{b}}$ & $223.55 \pm 0.30^{c}$ \\
\hline Gr V & D+Tolbutamide & $287.4 \pm 0.40^{\mathrm{a}}$ & $36.91 \pm 0.20^{c}$ & $92.5 \pm 0.30^{\mathrm{a}}$ & $38.1 \pm 0.82^{b}$ & $200.16 \pm 0.34^{a}$ \\
\hline
\end{tabular}

Values are given as mean $\pm S D(n=6)$. Values were statistically significant at ${ }^{a} P<0.05,{ }^{b} P<0.02,{ }^{c} P<0.01,{ }^{d} P<0.001$. Normal Vs D. control and Diabetic Control Vs Diabetic reated albino rats

\begin{tabular}{|c|c|c|c|c|c|}
\hline Groups & Treatment & AST (U/L) & ALT (U/L) & ALP (U/L) & GGT (U/L) \\
\hline Gr I & Normal & $40.9 \pm 2.26$ & $42.61 \pm 0.39$ & $23.55 \pm 0.62$ & $1.61 \pm 0.04$ \\
\hline Gr II & D. Control & $78.86 \pm 0.9^{c}$ & $56.65 \pm 0.36^{c}$ & $56.70 \pm 0.26^{b}$ & $1.46 \pm 0.03^{d}$ \\
\hline Gr III & D. control & $79.53 \pm 0.77$ & $58.83 \pm 0.23$ & $57.67 \pm 0.32$ & $1.35 \pm 0.02$ \\
\hline Gr IV & $\mathrm{D}+\mathrm{C}$. tamala & $47.83 \pm 0.7^{\mathrm{d}}$ & $44.75 \pm 0.6^{c}$ & $28.41 \pm 0.53^{c}$ & $1.55 \pm 0.01^{\mathrm{c}}$ \\
\hline Gr V & $\mathrm{D}+$ Tolbutamide & $49.11 \pm 0.6^{c}$ & $45.01 \pm 0.21^{\mathrm{NS}}$ & $32.68 \pm 0.35^{\mathrm{NS}}$ & $1.49 \pm 0.02^{c}$ \\
\hline
\end{tabular}

Values are given as mean $\pm S D(n=6)$. Values were statistically significant at ${ }^{a} \mathrm{P}<0.05,{ }^{b} \mathrm{P}<0.02,{ }^{\mathrm{C}} \mathrm{P}<0.01,{ }^{\mathrm{d}} \mathrm{P}<0.001$. Normal Vs $\mathrm{D}$. control and Diabetic Control Vs Diabetic treated albino rats 


\begin{tabular}{|c|c|c|c|}
\hline Groups & Treatment & $\begin{array}{c}\text { GSH } \\
\text { (nmole/g tissue) }\end{array}$ & $\begin{array}{c}\text { SOD } \\
\text { (IU/g tissue) }\end{array}$ \\
\hline Gr I & Normal & $9.77 \pm 0.12$ & $99.32 \pm 0.15$ \\
\hline Gr II & D. Control & $7.51 \pm 0.29^{d}$ & $72.51 \pm 0.32^{\mathrm{c}}$ \\
\hline Gr III & D Control & $7.25 \pm 0.19$ & $72.03 \pm 0.10$ \\
\hline Gr IV & $D+C$.tamala & $9.6 \pm 0.15^{c}$ & $93.13 \pm 0.15^{d}$ \\
\hline Gr V & $\mathrm{D}+\mathrm{To}^{\mathrm{b}} \mathrm{utam}^{\mathrm{d}} \mathrm{e}$ & $9.35 \pm 0.12^{\mathrm{c}}$ & $92.88 \pm 0.13^{b}$ \\
\hline
\end{tabular}

Values are given as mean $\pm S D(n=6)$. Values were statistically significant at ${ }^{\mathrm{P}} \mathrm{P}<0.05$, ${ }^{b} \mathrm{P}<0.02,{ }^{c} \mathrm{P}<0.01, \mathrm{~d} \mathrm{P}<0.001$. Normal Vs D. control and Diabetic Control Vs Diabetic treated albino rats

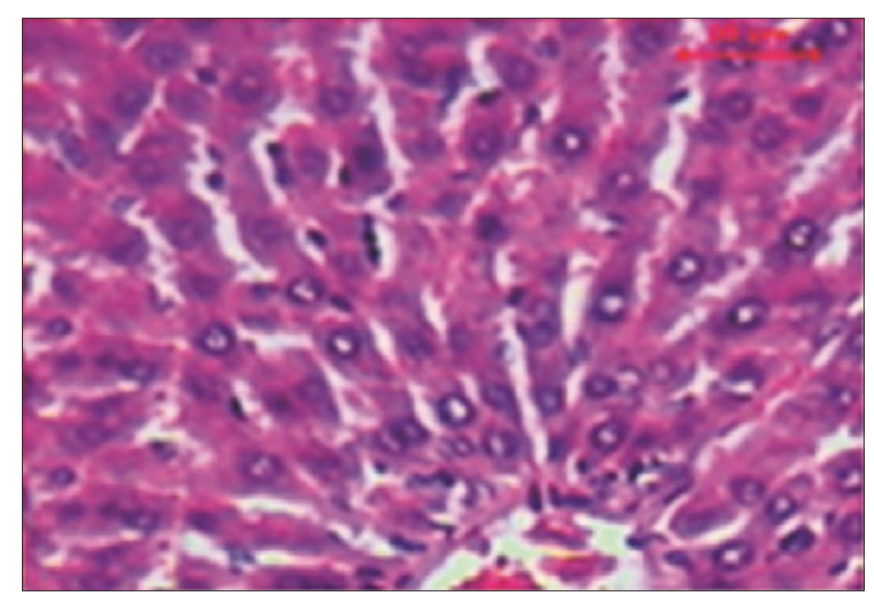

Figure 1: Normal control liver tissues showing normal cellular hepatocyte architecture

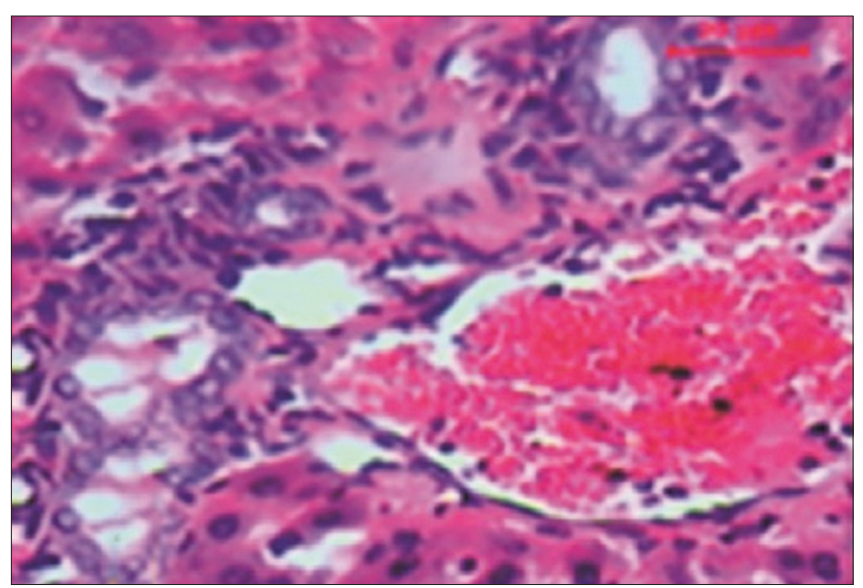

Figure 2: Alloxan induced diabetic control rats revealed massive degeneration and necrosis of hepatocytes, and cell swelling with vacuolar degeneration

Diversity of medicinal plants and spices containing various phytochemicals with biological activity serve as viable source of drugs for the world population. Several phenolics, flavonoids and alkaloids possess marked antidiabetic activities. ${ }^{30}$ In a previous study, terpenoids and flavonoids have been reported to increase the concentration of antioxidants. ${ }^{31}$ Rupasinghe et $\mathrm{al}^{32}$ have reported that

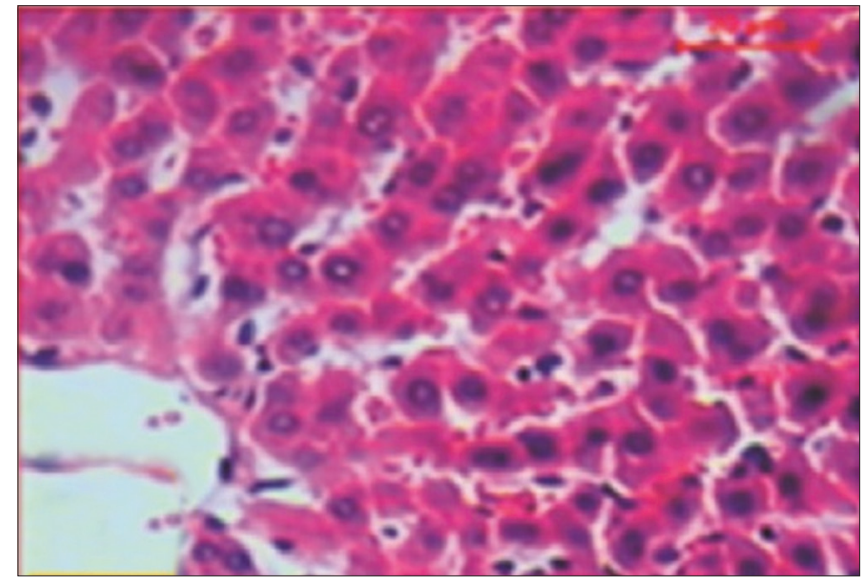

Figure 3: Rats treated with C. tamala showed mild amount of degeneration and more or less like of normal hepatocytes

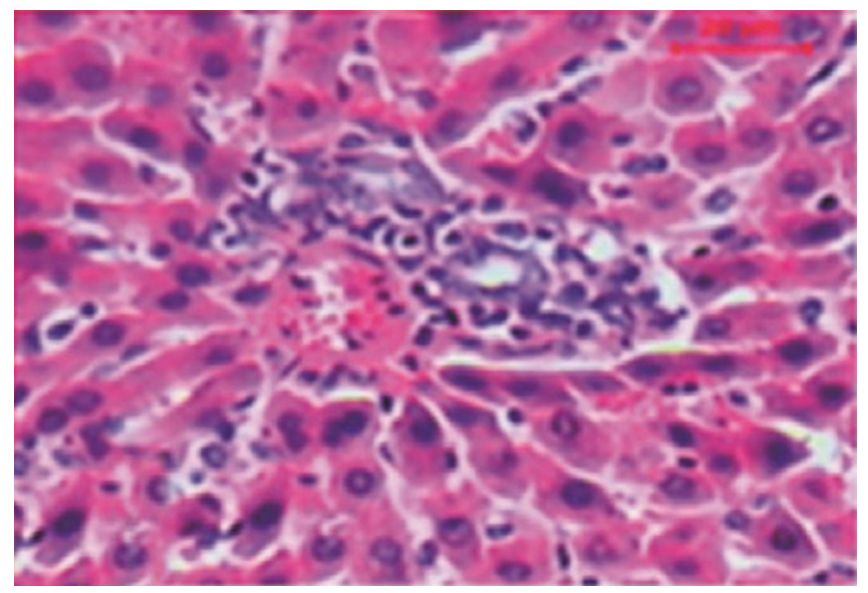

Figure 4: Rats treated with Tolbutamide showed a similarity with diabetic control appearance, not much change

saponins possessed hypocholesterolemic and antidiabetic properties. The presence of these phytochemicals supports the claim for the medicinal uses of C. tamala as potent antioxidant and hypoglycaemic agent.

After alloxan injection the rats showed higher glucose level and lower level of insulin when compared to normal control rats. From the results of the present study, it was observed that treatment with C. tamala extract decreased the serum glucose and increased serum insulin in diabetic rats. The possible mechanism for lowering of glucose level might be due to stimulation of insulin secretion from remnant pancreatic $\beta$-cells, either by promoting glucose uptake and metabolism, or by inhibiting hepatic gluconeogenesis. ${ }^{33}$ This is confirmed by histopathological observations which show that the structural integrity of islets of Langerhans was restored towards normalization.

The study showed that significant decreased the content of liver glycogen in diabetic rats. But after administration of herbal extract shows increased the glycogen content 
in rat liver to near normal. This might be because of enhanced rate of glycogenesis or inhibited glucogenolysis due to stimulation of insulin release resulting in improved mobilization of blood glucose towards liver glycogen reserve or storage. . $^{34,35}$

As per previous data reported by Udayakumar et al. ${ }^{36}$ Glycosylated haemoglobin is produced progressively and irreversibly through glycosylation of haemoglobin over a period of time and subsequent browning reaction is enhanced by increased glucose levels, and this glycation itself further induces the formation of oxygen-derived free radicals. It is stable till the life of the RBC and is unaffected by diet, insulin or exercise. Therefore, it is an excellent marker of overall glycemic control.A significant deceased in $\mathrm{HbA1}_{\mathrm{C}}$ observed with C. tamala treated rats, which could be due to the result of improved glycemic control by the extracts.

Glucose consumption (glycolysis) and production (gluconeogenesis) are the important process for maintaining the normal sugar, take place in the liver where several enzymes are involved.Insulin regulates carbohydrate metabolism via controlling the activities of numerous metabolic enzymes in the liver by modifying the uptake and consumption of glucose in target organs such as kidneys, skeletal muscles, and adipose tissues. ${ }^{37}$ In our study, it was found that the activity of hexokinase decreased in diabetic rats. Insulin deficiency is the characteristic of diabetes that leads to the impairment in the activity of this enzyme. But after treatment wih C. tamala increased the activity of this enzyme due to which glycolysis can be activated and the use of glucose may increase. These results support the earliest finding of phytochemicals and medicinal plants. ${ }^{38-40}$ Hence the finding suggests that extract was improving the glucose metabolism by increasing the utilization of glucose.

Decrease in activity of phosphoglucoisomerase might be expected to inhibit the proportion of glucose 6-phosphate metabolized via the glycolytic pathway. ${ }^{41}$

Aldolase, another key enzyme in the glycolytic pathway, increases in diabetes and this may be due to cell impairment and necrosis. ${ }^{42}$ In experimental diabetes the cells are subjected to alloxan induced-damage and very often exhibit glycolysis after a period of increased oxygen uptake.

Glucose-6-phosphatase is the key enzyme of gluconeogenic enzymes because it regulates both glycogenolysis and gluconeogenesis process. ${ }^{43,44}$ The activity of glucose 6 phosphatase in diabetic rats was increased in the liver as compared to normal rats, probably due to insulin insufficiency because under normal conditions insulin acts to suppress gluconeogenic enzymes. After treatment with C. tamala inhibited the glucose 6 phosphatase enzyme activity as reported in other studies on phytochemicals ${ }^{45}$, probably resulting in the restoration of blood glucose and glycogen content in the liver. This effect may be due to the presence of tannin, saponin, flavonoids and other constituents presence in the extract which could act synergistically or independently in enhancing the activity of glycolytic and gluconeogenic enzymes.

Lactate dehydrogenase (LDH) is the enzyme that helps to catalyze the interconversion of pyruvate to lactate and viceversa in the glycolysis process. ${ }^{46}$ Increased level of LDH activity in diabetic rats is linked with less insulin availability in diabetes. However, treatment with extract decreases the activity of LDH may be because this extract controls the amount of pyruvate and NADH, thus it helps to process oxidation of glucose in mitochondria. Similar findings were reported by others. ${ }^{47,48}$

Elevated levels of AST, ALT, ALP and GGT are indicative of cellular leakage and loss of functional integrity of the hepatic cell membranes implying hepatocellular damage. ${ }^{49}$ In the present study, after alloxan injection induces hepatocellular damage, which is one of the characteristic changes in diabetes as evidenced by high serum levels of AST, ALT, ALP and GGT in diabetes, suggesting possible damage to the liver. But after treatment with C. tamala showed a significant reduction in the levels of these enzymes when compared to the diabetic untreated control.Therefore it confirm that C. tamala has some hepatoprotective potentials in diabetic rats, thereby showing its non-toxic nature.

The free radicals and reactive oxygen species are might be playing an important role in causation and complications in diabetes mellitus. ${ }^{50}$ Vital tissues are capable for antioxidant defense mechanisms, which include the concerted action of both antioxidant enzymes and nonenzymatic antioxidants. Activities of altered antioxidant enzymes SOD and glutathione metabolism results in an imbalance of oxidant/antioxidant defense systems leading to the accumulation of highly reactive oxygen free radicals. ${ }^{51}$ In the present study, we observed a decrease in antioxidant enzymes markers in liver tissues of diabetic rats in addition to increased blood glucose with decreased plasma insulin levels. The alloxan induced diabetes is associated with the generation of ROS, which causes oxidative damage..$^{22}$ When these diabetic rats treated with C. tamala extract showed the proper functioning of hepatic tissues. Thus the extract of C. tamala might protect the liver tissues against the cytotoxic action of alloxan.

Histopathological examination of liver of diabetic rats revealed morphological changes. The effect of C. tamala 
on the histopathological changes of diabetic liver is promising.

\section{CONCLUSION}

In conclusion, our findings showed that C. tamala markedly reduced hyperglycemia and associated oxidative complications (increased antioxidants markers including enzymatic and nonenzymatic antioxidants) in alloxan induced diabetic rats. Thus, the present study has shown that the phytochemicals as total phenolics, total flavonoids present in C. tamala has protect the liver against alloxan induced diabetic rats due to decreasing the levels of oxidative markers and improvement of antioxidants systems and normalized the histopathological changes.

Experimental evidence obtained from this study is encouraging enough to warrant further studies on the C. Tamala leaves extract to find out its mechanism of action for treatment of diabetic complications.

\section{REFERENCES}

1. Ortiz-Andrade RR, Garc'la-Jim'enez $S$, Castillo-España $P$, Ram'irez- Avila G, Villalobos-Molina R and Estrada-Soto S. Alpha-Glucosidase inhibitory activity of the methanolic extract from Tournefortia hartwegiana: an anti-hyperglycemic agent. J Ethnopharmacol 2007; 109(1): 48-53.

2. American Diabetes Association (ADA). Diagnosis and classification of diabetes mellitus. Diabetes Care 2012; 33(Suppl. 1): S62-9.

3. Savu O, lonescu-Tirgoviste C, Atanasiu V, Gaman L, Papacocea $\mathrm{R}$ and Stoian I. Increase in total antioxidant capacity of plasma despite high levels of oxidative stress in uncomplicated type 2 diabetes mellitus. J Int Med Res 2012; 40(2): 709-716.

4. Neethu P, Haseena P, ZevaluKezo, Thomas SR, Goveas SW and Abraham A. Antioxidant properties of Coscinium fenestratum stem extracts on Streptozotocin induced type 1 diabetic rats. J Appl Pharm Sci 2014; 4(1): 29-32.

5. Yang H, Jin X, Kei Lam CW and Yan SK. Review: oxidative stress and diabetes mellitus. Clin Chem Lab Med 2011; 49(11): 1773-1782.

6. Gomathi D, Ravikumar G, Kalaiselvi M, Devaki K and Uma C. Efficacy of Evolvulus alsinoides (L.) L. on insulin and antioxidants activity in pancreas of streptozotocin induced diabetic rats. J Diabetes Metab Disord 2013; 12(1):39.

7. Arumugam G, Manjula P and Paari N. A review: Anti diabetic medicinal plants used for diabetes mellitus. J Acute Dis 2013; 2(3):196-200.

8. Noor A, Bansal VS and Vijayalakshmi MA. Current update on anti-diabetic biomol- ecules from key traditional Indian medicinal plants. Curr Sci 2013; 104(6):721-727.

9. Uddin NS. Traditional Uses of Ethnomedicinal Plants of the Chittagong Hill Tracts. Bangladesh National Herbarium, Dhaka; 2006:446.

10. Bisht S and Sisodia SS. Assessment of antidiabetic potential of Cinnamomum tamala leaves extract in streptozotocin induced diabetic rats. Indian J of Pha 2011; 43:582585.

11. Kumanan R, Manimaran S, Saleemulla K, Dhanabal SP and Nanjan MJ. Screening of bark of Cinnamomum tamala (Lauraceae) by using aamylase inhibition assay for antidiabetic activity. Int J Pharm Biomed Res 2010;1:4548.

12. Chakraborty $\mathrm{U}$ and Das $\mathrm{H}$. Antidiabetic and antioxidant activities of Cinnamomum tamala leaf extracts in stztreated diabetic rats. Glob J Biotech Biochem 2010;5:1218.

13. Trinder P. Determination of glucose in blood using glucose oxidase with an alternative oxygen accepter. Ann. Clin. Biochem 1969; 6: 24-25.

14. Nayak SS and Pattabiraman TN. A new colorimetric method for the estimation of glycosylated hemoglobin. Clinica Chimica Acta 1981; 109(3):267-274.

15. Andersen L, Dinesen B, Jorgensen PN, Poulsen F and Roder ME. Enzyme immunoassay for intact human insulin in serum or plasma. Clinical Chemistry 1993; 39(4):578-582.

16. van der Vies J. Two methods for the determination of glycogen in liver. Biochemical Journal 1954; 57(3):410-416.

17. Branstrup N, Krik JE and Bruni C. The hexokinase and phosphoglucoisomerase activities of aorta and pulmonary artery tissue in individuals of various ages. J Gerontol 1957; 12: 166 -171.

18. Horrocks JE, Ward $\mathrm{J}$ and King J. A routine method for the determination of phosphoglucoisomerase activity in body fluid. J Clin Pathol 1963; 16: 248-251.

19. King J. The hydrolases-acid and alkaline phosphatase. Practical Clinical Enzymology. Van, D. Eds., Norstand company Ltd. 1965; 83-93.

20. Lorentz K, Klauke R and Schmidt E. Recommendation for the determination of the catalytic concentration of lactate dehydrogenase at $37{ }^{\circ} \mathrm{C}$. Eur $\mathrm{J}$ Clin Chem Clin Biochem 1993;31:897-899.

21. King, J. The dehydrogenase or oxido reductaselactate dehydrogenase. Practical Clinical Enzymology, Van, D. Eds., Norstand company Ltd. 1965; 83-93.

22. IFCC mehods for the measurement of catalytic concentrations of enzymes. J Clin Chem Clin Biochem 1986; 24:497.

23. Kind PRN and King EJ. Estimation of Plasma Phosphatase by Determination of Hydrolysed Phenol with Amino-antipyrine. J Clin Pathol 1954; 7(4): 322-326.

24. Ohkawa $\mathrm{H}$, Ohishi $\mathrm{N}$ and Yagi $\mathrm{K}$. Assay for lipid peroxides in animal tissues by thiobarbituric acid reaction. Anal. Biochem 1979; 95(2):351-358.

25. Minami $\mathrm{M}$ and Yoshikawa $\mathrm{H}$. A simplified assay method of superoxide dismutase activity for clinical use. Clin Chim Acta 1979; 92 (3):337-342.

26. Lillie RD. Histopathologic technic and practical histochemistry. $3^{\text {rd }}$ ed. New York: McGrawHill Co., 1965;715.

27. Wild S, Roglic G, Green A, Sicree R and King H. Global prevalence of diabetes: estimates for the year 2000 and projections for 2030. Diabetes Care 2004; 27 (5):1047-1053.

28. Narváez-Mastache JM, Soto C and Delgado G. Hypoglycemic and antioxidant effects of subcoriacin in normal and streptozotocin-induced diabetic rats. J Mex Chem Soc 2010; 54 (4):240-244.

29. Wang R, Ding G, Liang W, Chen C and Yang H. Role of LOX-1 and ROS in oxidized low-density lipoprotein induced epithelialmesenchymal transition of NRK52E. Lipids Health Dis 2010; 9:120.

30. Hsu F, Chen $Y$ and Cheng J. Caffeic. Acid as active principle form the fruit of Xanthium strumarium to lower plasma glucose in diabetic rats. Planta Medica 2000; 66(3):228-230.

31. Luo J, Cheung $\mathrm{J}$ and Yevich E. Novel terpenoidtype quinones isolated from Pycnanthu angolensis of potential utility in the 
treatment of type-2 diabetes. J Pharm Exp Ther 1999; 288: 529-534.

32. Rupasinghe HP, Jackson CJ, Poysa V, Di Berardo C, Bewley JD and Jenkinson J. Soyasapogenol A and B distribution in Soybean (Glycine max L.Merr) in relation to seed physiology, genetic variability and growing location. J Agric Food Chem 2003; 51(20):5888-5894.

33. Saravanan G, Ponmurugan P, Kumar GPS and Rajarajan T. Antidiabetic properties of S-allyl cysteine, a garlic component on streptozotocin-induced diabetes in rats. J Appl Biomed 2009; 7:151-115.

34. Chakrabarti S, Biswas TK, Rokeya B, Ali L, Mosihuzzaman M, Nahar N, et al. Advanced studies on the hypoglycemic effect of Caesalpinia bonducella in type 1 and type 2 diabetes in Long Evans rats. J Ethnopharmacol 2003; 84(1):41-46.

35. Sharma B, Sarapathi SK and Roy P. Hypoglycemic and hypolipidemic effect of Aegle marmelos (L.) leaf extract on streptozotocin induced diabetic rats. Int J Pharm 2007; 3(6): 444-452.

36. Udayakumar R, Sampath K, Thankaraj SM, Rajesh M, Anbazhagan VR, Kim SC, et al. Hypoglycaemic and Hypolipidaemic Effects of Withania somnifera root and leaf extracts on alloxan-induced diabetic rats. Int J Mol Sci 2009; 10(5):2367-2382.

37. Pavana P, Sethupathy S and Manoharan S. Antihyperglycemic and antilipidperoxidative effects of Tephrosia purpurea seed extract in streptozotocin induced diabetic rats. Ind J Clin Biochem 2007; 22(1):77-83.

38. Rathi SS, Grover JK and Vats V. The effect of Momordica charantia and Mucuna pruriens in experimental diabetes and their effect on key metabolic enzymes involved in carbohydrate metabolism. Phyto Res 2002;16(3):236-243.

39. Pari L and Suman S. Efficacy of naringin on hepatic enzymes of carbohydrate metabolism in streptozotocin-nicotinamide induced type 2 diabetic rats. Int J Pharm Biol Arch 2010;1(2):280-286.

40. Grover JK, Vats $\vee$ and Rathi SS. Anti-hyperglycemic effect of Eugenia jambolana and Tinospora cordifolia in experimental diabetes and their effects on key metabolic enzymes involved in carbohydrate metabolism. J Ethnopharmacol 2000; 73(3): 461-470.

41. Ebrahim AS, Babakrishnan $K$ and Sakthisekaran D. Perchloroethylene - induced alterations in glucose metabolism and their prevention by 2 deoxy-D-glucose and vitamin $E$ in mice. J Appl Toxicol 1996; 16: 339-348.
42. Arathi $G$ and Sachdanandam. Therapeutic effect of Semecarpus and Cardium Linn, nut milk extract on carbohydrate metabolizing and mitochondrial TCA cycle and respiratory chain enzymes in mammary carcinoma rats. J. Pharm and Pharmol 2003; 55(9): 1283-1290.

43. Mithieux G, Rajas F and Gautier-Stein A. A novel role for glucose 6-phosphatase in the small intestine in the control of glucose homeostasis. J Biol Chem 2004; 279(43):44231-44234.

44. Ragavan B and Krishnakumari S. Antidiabetic effect of T. arjuna bark extract in alloxan induced diabetic rats. Ind $\mathrm{J}$ Clin Biochem 2006; 21(2):123-128.

45. Rajeswara Reddy S, Lavany T and Ganapathi Narasimhulu KS. Effect of pimpinellatirupatiensison oxidative enzymes in STZinduced diabetic rat kidney. Iran J Pharma Res 2012;11:277-286.

46. Talaiezadeh A, Shahriari A, Tabandeh MR, Fathizadeh $P$ and Mansouri S. Kinetic characterization of lactate dehydrogenase in normal and malignant human breast tissues. Cancer Cell Int 2015; 15:19-27.

47. Giribabu N, Eswar KK, Swapna RS, Muniandy S and Salleh N. Vitis vinifera (Muscat Variety) seed ethanolic extract preserves activity levels of enzymes and histology of the liver in adult male rats with diabetes. Evid Based Complement Alternat Med. 2015; Article ID 542026: 8 pages.

48. Visweswara Rao P, Madhavi K, Dhananjaya Naidu M and Gan SH. Rhinacanthus nasutus ameliorates cytosolic and mitochondrial enzyme levels in streptozotocin-induced diabetic rats. Evid Based Complement Alternat Med 2013; Article ID 486047:6 pages.

49. Moulisha B, Karan TK, Kar B, Bhattacharya S, Ghosh AK, Kumar RB, et al. Hepatoprotective activity of Terminalia arjuna leaf against paracetamol-induced liver damage in rats. Asian J Chem 2011; 23:1739-1742.

50. Yang $\mathrm{H}$, Jin $\mathrm{X}$, Lam CWK and Yan SK. Oxidative stress and diabetes mellitus. Clinical Chemistry and Laboratory Medicine 2011; 49(11):1773-1782.

51. Wang $X$ and Hai CX. ROS acts as a double-edged sword in the pathogenesis of type 2 diabetes mellitus: is Nrf2 a potential target for the treatment? Mini-Reviews in Medicinal Chemistry 2011; 11(12):1082-1092.

52. Matsunami T, Sato Y, Hasegawa Y, Ariga S, Kashimura S, Sato $T$, et al. Enhancement of reactive oxygen species and induction of apoptosis in streptozotocin-induced diabetic rats under hyperbaric oxygen exposure. International Journal of Clinical and Experimental Pathology 2011; 4(3):255-266.

\section{Authors Contribution:}

MP- Concept of the study, setting research methodology, managing logistics, sample collection, processing and analyzing the result and writing the manuscript

Work attributed to: Government Medical College, Nagpur

Orcid ID:

Dr. Mamta Pochhi - (i) https://orcid.org/0000-0002-8555-1316

Source of Support: Self funded, Conflict of Interest: None declared. 